NASA Technical Memorandum 100211

\title{
Test Stand Performance of a Convertible Engine for Advance V/STOL and Rotorcraft Propulsion
}

\author{
(NASA-TM-100211) TEST STAND PEEFOEMANCE OE \\ A CONVERTIBLE ENGINE FOR ADVANCED V/STOL AND \\ ROTOECEAFT PROQULSTON (NASA) 22 p Avail: \\ NTIS IIC AO3/MF AOI \\ CSCL $21 \mathrm{E}$

Jack G. McArdle

Lewis Research Center

Cleveland, Ohio

Prepared for the International Powered Lift Conference sponsored by the Society of Automotive Engineers Santa Clara, California, December 7-10, 1987 
TEST STAND PERFORMANCE OF A CONVERTIBLE ENGINE FOR ADVANCED V/STOL

\author{
AND ROTORCRAFT PROPULSION
}

\author{
Jack G. McArdle \\ National Aeronautics and Space Administration \\ Lewis Research Center \\ Cleveland, Ohio 44135
}

\begin{abstract}
SUMMARY
A variable inlet guide vane (VIGV) convertible engine that could be used to power future high-speed V/STOL and rotorcraft was tested on an outdoor stand. The engine ran stably and smoothly in the turbofan, turboshaft, and dual (combined fan and shaft) power modes. In the turbofan mode with the VIGV open, fuel consumption was comparable to that of a conventional turbofan engine. In the turboshaft mode with the VIGV closed, fuel consumption was higher than that of present turboshaft engines because power was wasted in churning fan-tip airflow. In dynamic performance tests with a specially built digital engine control and using a waterbrake dynamometer for shaft load, the engine responded effectively to large steps in thrust command and shaft torque.
\end{abstract}

\title{
INTRODUCTION
}

A convertible engine can produce turbofan thrust, turboshaft power, or any combined thrust and shaft power continuously while operating up to full speed. Convertible engines could be used to power vertical/short-takeoff-and-landing (V/STOL) airplanes and advanced high-speed rotorcraft such as those shown in figures 1 and 2 . The V/STOL applications include thrust modulation, directional control, and fan cross-coupling for two-engine configurations to improve safety in case one engine should fail. These features, as used on the Vought V530 and Grumman 698 airplanes (ref. 1) are feasible because convertible engine thrust and power can be varied quickly by changing engine geometry rather than engine speed. For rotorcraft a convertible engine would operate as a turboshaft engine to drive a lifting rotor for vertical and low-speed horizontal flight, and as a turbofan engine to produce thrust for high-speed horizontal flight.

In a convertible engine the power turbine drives both the fan and an output shaft connected to some other load. Total turbine power is just the sum of the powers absorbed by all the loads; therefore any turbine power over that needed by the fan is available at the power output shaft. Maximum turbine power is limited by cycle temperature (fuel flow) and speed. For high thrust the shaft load is reduced or decoupled, as by releasing a clutch. When shaft power is required, the fan is unloaded aerodynamically. Two general methods have been devised to unload the fan (ref. 2). One method is based on variablepitch fan blades - fan power is reduced as the pitch is made "flatter." This method has been demonstrated in tests of engines such as QCSEE (ref. 3), Q-fan (ref. 4), and Astafan (tested successfully as a convertible engine in a U.S. Army Research and Technology Laboratories test program). The other method is based on variable inlet guide vanes (VIGV) that can be deflected to change fan airflow and inflow swirl - fan power is reduced as the vanes are closed. This method has been demonstrated in fan research tests (ref. 5) and in tests of a high-bypass-ratio turbofan engine with no output shaft power (ref. 6). 
Recognizing the potential installation and performance advantages of convertible engines, the Defense Advanced Research Project Agency (DARPA) and the National Aeronautics and Space Administration (NASA) joined in a Convertible Engine System Technology (CEST) Program to establish the feasibility of the convertible engine concept. This program expanded basic technology, generated design criteria, and provided data and experience applicable to engines and controls for future convertible propulsion systems. The program included defining requirements for convertible engine systems and evaluating an engine type that could be used on advanced aircraft including several V/STOL designs (ref. 1), the X-wing (refs. 7 and 8 ), and the folding tilt rotor (refs. 9 and 10) (in which use of a new torque converter was proposed to uncouple the fan for shaft-only power). The experimental work described in this report was done at NASA Lewis Research Center. The engine was a TF34-400B (8000-1b-thrust class) turbofan modified to a VIGV convertible engine. The tests were performed on an outdoor test stand with a waterbrake dynamometer used for the shaft load. For some tests a new digital electronic system was used to control engine speed and variable-geometry actuators. The test objectives were to demonstrate operation of this type of convertible engine in the turbofan, turboshaft, and dual (combined fan and shaft) power modes and to evaluate the effects of the new and modified components on performance through internal flow path measurements.

The tests included steady-state and dynamic performance tests plus engine response to simulated aircraft maneuvers requiring fast response to changes in thrust or shaft torque command. In many cases, the results will be interpreted for application to V/STOL propulsion requirements. The engine tests are summarized in this paper by showing typical results at selected operating conditions. Detalied results and a more thorough discussion of the steady-state tests are given in reference 11 .

\section{NOMENCLATURE}

F engine gross thrust, 1 ib

$F_{R} \quad$ referred engine gross thrust, $1 \mathrm{~F} / \delta$

NF fan, power-output-shaft, and power-turbine speed, percent of rated
speed

NF $F_{R}$ referred fan, power-output-shaft, and power-turbine speed, NF/ $\theta$, percent of rated speed

PWSD output shaft power, hp

PWSD $R$ referred output shaft power, PWSO/S $\theta$

$T$ temperature, ${ }^{\circ} \mathrm{R}$

T4.5 power-turbine inlet total temperature, ${ }^{\circ} \mathrm{R}$

lCalled "gross thrust" because, by convention with the TF34 engine, the reported thrust is net (measured in test stand) thrust plus calculated core cowling scrubbing drag. 

T4.5R referred power-turbine inlet total temperature, $T 4.5 /(\theta) 0.84$
T4.5R,L upper limit of power-turbine inlet total temperature for standard TF34 engine, ${ }^{\circ} R$

WA12 fan-tip airflow, $1 \mathrm{~b} / \mathrm{sec}$

WA12R referred fan-tip airflow, WA12 $\theta / \delta$

WF fuel flow rate, $\mathrm{lb} / \mathrm{hr}$

$W F_{R}$ referred fuel flow rate, $W F / \delta \theta$

$\delta \quad$ ratio of pressure to $14.696 \mathrm{psi}$

$r \quad$ ratio of temperature to $518.7^{\circ} \mathrm{R}$

\section{APPARATUS AND PROCEDURE}

\section{Engine}

The test engine was a previously used TF34-400B especially modified by the manufacturer as sketched in Fig. 3. The standard TF34 is a $6: 1$ bypass ratio turbofan that can produce $9100 \mathrm{lb}$ of sea-level-static thrust. The single-stage fan is driven by a four-stage low-pressure turbine. The core has a 14-stage axial compressor, an annular combustor, and a two-stage high-pressure turbine.

The engine modifications, shown in more detail in figure 4 , were made by using as many existing parts as feasible. The resulting configuration, called the CEST TF34, was not meant to be a production engine. The fan was unloaded aerodynamically by deflecting part-span VIGV to change the rate and swirl angle of the flow entering the fan tip. The vanes are "part span" because they reach only from the outer wall to the core/bypass flow splitter and thus have little effect on core flow. When the vanes are deflected, the fan air load is reduced and the power turbine can drive an external load through the power output shaft.

Each of the major modifications is described in the following paragraphs. For additional detail, consult references 11 and 12 .

Variable inlet guide vanes. - A set of 30 vanes was installed just ahead of the fan rotor to unload the fan in the turboshaft power mode. Each vane consisted of a fixed forward strut and a movable rear flap. The flaps were deflected together by a hydraulic actuator system.

Flow splitter. - The core/bypass flow splitter was extended forward to the VIGV to minimize core inlet flow distortion from the deflected VIGV.

Fan blades. - Full-chord shrouds, continuing the core/bypass flow splitter, were added to the standard TF34 fan blades. The shrouds were hol low to reduce weight, and contained seals to minimize leakage between the hub and tip flows. In addition, the hub airfoil shape was changed to improve pumping performance in the low-aspect-ratio passage formed by the hub/splitter annulus. 
Variable exit guide vanes. - A set of 44 variable exit guide vanes (VEGV) replaced the same number of standard TF34 exit stator vanes in the fan-tip (bypass) flow. Deflection of the new vanes by hydraulic actuators was scheduled to VIGV deflection to prevent stall buffetting at high VIGV closure such as was encountered in previous tests of a similar configuration (ref. 6 ).

Bleed valve. - A core/bypass bleed valve was installed in the flow splitter behind the VEGV to improve the fan-hub/core-engine flow match at low-power operation. The valve was a sliding-ring valve moved by three actuators evenly spaced around the core engine.

Shaft extension. - The power output shaft extended forward from the fan disk. The extension included a flexible coupling and bearings supported by spider struts built into the inlet ducting.

\section{Control Systems}

For the CEST TF34, fan speed and thrust were controlled by the engine control system, and shaft torque (power) was controlled by the waterbrake torque control.

Engine control system. - A new digital control system (described in (ref. 13)) was supplied with the engine. The system worked together with the standard TF34 fuel control in two operating modes.

(1) In the "shaft" mode the digital system varied the VIGV (open 10op) to match the thrust command input and adjusted the fuel to hold the fan speed steady (closed (oop) as the output shaft torque changed.

(2) In the "thrust" mode the digital system locked the VIGV in the fully open position and controlled the fan speed to a preprogrammed schedule copen loop) to match the thrust command input.

In both modes the control also adjusted the VEGV and the bleed valve to positions determined from internally programmed schedules.

Waterbrake torque control. - The waterbrake torque control system adjusted the power output shaft torque (closed 100p) to match the torque command input. Control was accomplished by positioning the exit flow valve to vary the water annulus level in the waterbrake. The water throughflow rate, and thus the water temperature rise, was set by sizing the inlet flow valve.

The excellent performance of the waterbrake and its control is indicated by its response to a large torque command step (fig. 5). The exit flow valve, driven by a large hydraulic actuator and a high-response electrohydraulic servovalve, moved fast enough to change torque at a rate of more than $12000 \mathrm{ft}-1 \mathrm{~b} / \mathrm{sec}$. For the test shown the engine fuel flow was fixed (nominally constant engine power) and the water inlet valve was of maximum size. For smaller inlet valve openings the torque changed at a lower rate because the water annulus filled more slowly. The initial dead time in torque response may have been caused by an unexplained flow effect within the waterbrake; its presence caused no problems in the tests reported herein but might limit other types of control transient testing that can be done successfully with this type of power absorber. 
Test Facility and Engine Installation

The engine was tested on an outdoor static test stand at NASA Lewis (fig. 6). The separate-flow exhaust nozzles were standard TF34 nonadjustable nozzles. The power output shaft was supported by a pedestal just in front of the bellmouth and then connected to the waterbrake. A honeycomb screen flow straightener was located at the bellmouth. The honeycomb caused up to 2-percent total-pressure loss but reduced inlet distortion that might have been caused by the shaft support pedestal. The residual distortion near the fan face, indicated by the conventional gradient parameter (Maximum total pressure - Minimum total pressure)/Average total pressure, was only about 0.5 percent.

Total-pressure rakes, wall-pressure orifices, thermocouples, load cells, fuel flowmeters (both turbine and beam types), and other conventional instrumentation transducers were used to measure steady-state engine operation and internal flow path performance. Because transient engine changes were slow enough that the necessary transducers could follow the changes satisfactorily, no special dynamic performance instrumentation was required. A photoelectric scanner (ref. 14) was used to monitor fan-blade-tip motions for possible aeromechanical instability.

\section{Procedure and Data Recording}

Steady-state tests. - The steady-state tests were performed with the engine running at constant referred speed. The engine VIGV, VEGV, and bleed valve positions, plus the waterbrake torque, were adjusted manualiy as desired. Performance data were averaged from several (usually 20) scans through the instrumentation list. Computed results are referred to the engine inlet plane just ahead of the VIGV.

Dynamic tests. - Some of the dynamic tests were performed with the engine control in the thrust mode, but most were performed in the shaft mode because that mode is more typical of V/STOL and rotorcraft operation. After steadystate data were taken to define the transient end points, the transient was performed with thrust command to the engine control and torque command to the waterbrake torque control. Both commands were generated by programmable facility controllers. The commands and selected performance data were recorded on magnetic tape and later digitized or played back on strip charts for analysis.

\section{CEST TF34 TEST RESULTS AND DISCUSSION}

The test results presented in this report were obtained on an outdoor static test stand and are referred (corrected) to sea-level-static, standardday conditions at the engine inlet. Symbols used in this report are defined in an appendix.

\section{Steady-state Tests}

Data are shown for a referred fan speed $N F_{R}$ of 90 percent, and are representative of performance for speeds of 70 to 100 percent. Complete test results are contained in reference 11 . 
Thrust and shaft power. - When the engine is running with no output shaft power, it is said to be operating in the turbofan mode; when it is running at limiting power-turbine inlet temperature $T 4.5 \mathrm{R}, \mathrm{L}$, in the turboshaft mode; when it is running with both thrust and shaft power, in the dual power mode.

As shown in figure 7 , at constant referred fan speed the shaft power in the turboshaft mode was greatest with the VIGV closed. As the power-turbine inlet temperature $T 4.5_{R}$ was reduced by decreasing fuel flow at any fixed VIGV position, the engine produced less shaft power when running in the dual power mode, but the thrust was reduced only slightly because the fan-tip flow and the speed were the same. In the turbofan mode the thrust was highest with the VIGV open. Although the thrust decreased as the VIGV closed, thrust never went to zero. Residual thrust was mainly from the core engine. The engine was stable as speed, output shaft power, and any of the variable engine hardware settings were changed. It ran smoothly in all modes, except for a small region of fantip aero-mechanical instability at high VIGV closure and high fan speed. The instability is not considered to be a problem in a new VIGV type of convertible engine. Instability could be avoided by designs which either reduce the bladetip aspect ratio or include part-span shrouds or dampers.

The success of these tests, the first for a VIGV convertible engine running in the dual power mode, demonstrated that this type of engine is suitable for applications needing both thrust and shaft power.

Power balance. - When the VIGV were closed, the fan was unloaded by changing the tip airflow and the inflow swirl. In the turboshaft mode as the VIGV were closed, airflow fell off until at full closure it was reduced by 90 percent (fig. 8). By design, some throughflow remained with the VIGV closed in order to cool fan-stage parts heated by churning. The fan-hub power was essentially constant as the airflow changed (fig. 9 ) because the speed was steady and because the bleed valve was opened to keep hub flow constant at low power. The tip power fell off as the VIGV were closed to about 60 percent and then remained the same for further closure. The constant tip power, in view of the decreasing tip airflow, indicates worsening compression efficiency and more power lost in churning the tip airflow. With fully closed VIGV the tip wasted 23 percent of the turbine power in churning. Reduction in the churning loss would add to available shaft power. However, churning losses as large as those measured on the CEST TF34 may not be detrimental for high-speed rotorcraft applications in which engine size is determined by the thrust needed for cruise flight. As an example the power requirement for a conceptual $X$-wing is shown in figure 10. In rotary-wing flight this aircraft would use only 30 percent of the power that it needs for high-speed, horizontal, fixed-wing flight. An engine having performance like the CEST TF3 could easily meet this requirement.

Another way to view engine behavior is to consider a power balance for the engine running at constant fan speed in the dual power mode with partially closed VIGV. A typical power balance for this type of operation is shown in figure 11. Both the fan-hub and fan-tip powers were neariy constant as shaft power was raised ( $f i g .11$ ) because both of those powers depend on speed and VIGV closure. Turbine power went up with shaft power, and T4.5R rose as fuel was added to provide this power. The turbine and hub powers are easily computed from component maps and cycle computer programs. When the tip power is computed (using known methods at open VIGV) or estimated (closed VIGV), the power balance is complete and engine performance is defined. 
As discussed previously, the tip churning power loss is dependent on airflow and compression efficiency. Because of instrumentation limitations the efficiency reported in figure 12 is based on fan-inlet and fan-nozzle measurements and thus includes the pressure loss in the bypass ducting. With open VIGV the efficiency was good and was close to the value predicted analytically by the engine manufacturer. As the VIGV were closed, efficiency fell to nearly zero. The poor efficiency at high closure seems to be related to unusual fan airflow behavior. During testing it was observed that the fan pumped air radially outward when the VIGV were closed past about 75 percent, resulting in flow concentration along the fan-case wall and leading to high turbulence and recirculation in the duct behind the fan stage (ref. 11). The poor efficiency produced high tip outflow temperatures - values as high as 1.5 times the inlet temperature (as much as a $250^{\circ} \mathrm{F}$ rise) were measured.

Fan research tests reported in reference 5 were done with a VIGV/fan rotor/VEGV different from the CEST TF34 design. Several differences from the CEST performance were measured, including significantly lower churning power loss with closed VIGV. The lower loss was obtained with the VEGV closed also (not done with CEST), but the rotor-exit temperature reached almost $500^{\circ} \mathrm{F}$. Better understanding of fan flow behavior with closed VIGV might lead to designs that successfully reduce flow and churning loss without thermal or mechanical problems.

Specific fuel consumption. - For high-speed cruise flight a convertible engine would be run in the turbofan mode at low VIGV closure to produce high thrust, and thrust specific fuel consumption (SFC) would be most important. The test results (fig. 13) show that for this type of operation the thrust SFC was very nearly the same as that for the unmodified engine. The reason was that the only significant change in fuel use came from the inlet pressure loss across the VIGV, which was small. The large rise in SFC at high VIGV closure was due to low thrust rather than to a sudden increase in fuel flow.

In the turboshaft mode only the output shaft power is used to compute power SFC. Because most of the fuel is used to produce thrust at low VIGV closure, the power SFC is very high. A convertible engine probably would not be operated in this way just to produce power; therefore the poor power SFC is of no real interest. As the VIGV were closed, more of the turbine power went to the shaft load, and the power SFC improved. The best power SFC was obtained with fully closed VIGV, but it was st 11 not as good as that of modern shaft engines mainly because of tip churning loss. These characteristics probably would be acceptable for a high-speed rotorcraft in which high shaft power normally is needed only during takeoff and landing. For aircraft in which hover is a large portion of the mission, the convertible engine would use significantly more fuel than a conventional shaft engine.

In the dual power mode the definition of SFC is complicated because there is no general way to apportion total fuel between thrust and shaft power. Describing engine performance in terms of power-turbine SFC or block fuel used during a particular manuever or mission would be satisfactory. 


\section{Dynamic Tests}

The dynamic tests were performed using the digital engine control system to control the VIGV, the VEGV, and the bleed valve and to hold fan speed constant when the engine was run in the shaft control mode.

Simulated rotorcraft maneuvers. - The engine was commanded to provide the estimated thrust and shaft power requirements at constant fan speed for several rotorcraft maneuvers ( $f i g .14$ ). The requirements came from the $X$-wing study of reference 7 and included a takeoff with sufficient "thrust" for vector control. The $X$-wing conversion requirements were based on the same study but modified to account for loss of engine thrust due to inlet momentum at conversion speed. The resulting transient exercised the engine over the same core engine changes as conversion at 5000-ft altitude and $250 \mathrm{kn}$. All the tests, except gust response, were done with control anticipation. The engine responded stably and effectively in every test (table I).

Thrust-step response. - Engine response (fig. 15) to a large thrustcommand step was much quicker in the shaft control mode (speed constant; VIGV changing) than in the thrust control mode (VIGV locked; speed changing) because the fan did not have to accelerate. The data suggest that the response was limited only by the VIGV slewing rate. This attribute would be useful for thrust vector control but might require large actuators.

The dead time ( 50 msec) between command input and VIGV action can be partially explained by hysteresis from mechanical wear in the VIGV actuation system and by digital data synchronization in the engine control system. Further investigation of this dead time was not possible within the scheduled test period.

Torque-step response. - The engine responded effectively to a large torque change (fig. 16). The waterbrake fulfilled the torque command in $1.5 \mathrm{sec}$. Anticipation circuits in the engine control gave an initial fuel surge that caused overtorque in the power turbine and a consequent increase in speed. Then the speed control reacted to reduce fuel, resulting in speed droop. The speed overshoot was 2.6 percent, and the droop was 5.8 percent. These variations are within a range comparable to that of modern production shaft engines. The overshoot could be reduced by optimizing the anticipation circuitry gain, and the droop could be minimized by optimizing the fuel/speed loop gain.

\section{Cross-shafted Convertible Engines}

Two-engine V/STOL aircraft powered with convertible engines could use the engines for roll control in powered-lift flight by modulating engine thrust. However, if one of the engines lost power the unbalanced thrust could lead to a rollover crash. For safety, the engines might be interconnected so that if one engine failed the "good" engine could power both sides to keep the craft level, although with reduced total thrust. A simple mechanical cross-shaft interconnection for VIGV engines is sketched in figure 17. The performance of this system with one of the core engines inoperative (such as a type I fuel system failure or a type II fan shaft fracture behind the cross-shaft gearbox) is illustrated in figure 18. Before the failure both engines would run normally with little or no shaft load, as shown on the steady-state map in figure 18(a). After failure, the inoperative engine would lose core thrust, but its fan 
(driven by the cross shaft at the same speed as the good engine), would still produce thrust. The fan thrust can be modulated by the VIGV, and as indicated in figure $18(\mathrm{~b})$, as the thrust is varied the power required to drive the fan is changed. The good engine can provide this power, and maximum power is available when the fuel flow is increased to move the operating point to the limiting power turbine inlet temperature line, as noted in figure $18(\mathrm{c})$. For balance the fan on the failed side must produce the same thrust as the fan plus core of the good engine. The required operating point is at the intersection of the two operating lines, as in figure $18(d)$. The intersection is reached by proper settings of both VIGV's, and thrust unbalance would occur if either setting is not correct. Results of the CEST engine steady-state tests indicated that balanced thrust would be obtained at the following conditions:

\begin{tabular}{|c|c|c|}
\hline & "Good" engine & "Inoperative" engine \\
\hline $\begin{array}{c}\text { Assumed condition for sea-level static } \\
\text { standard-day flight (e.g., hover) }\end{array}$ & $\begin{array}{c}\text { Normal operation at } \\
\text { limiting PTIT }\end{array}$ & $\begin{array}{c}\text { Complete core failure, } \\
\text { fan ok }\end{array}$ \\
\hline Fan speed, percent & 90 & 90 \\
VIGV, percent closed & 40 & 16 \\
Cross-shaft power, percent of & provides 89 & 69 \\
maximum output shaft power & & 66 \\
Thrust, percent of one-engine & 66 & \\
maximum & & \\
\hline
\end{tabular}

A control system that operates the VIGV's properly during failure seems feasible. The rudimentary characteristics of a conceptual design are illustrated in figure 19. A failure detector might be a manual switch or a signal from the cross shaft (which begins to transfer power if both engines are not operating the same). At failure, the control system would increase fuel flow to the good engine to raise its power turbine inlet temperature to the limit, and at the same time change each of the VIGV's to approximately the final angles. This action would require a logic system plus a schedule derived from engine performance testing. The VIGV settings must be trimmed by the control system from aircraft roll information, as engine thrust in flight is difficult to measure accurately. Additional control system requirements would depend on the particular aircraft application. Unfortunately, simulated failure tests were not made with the CEST engine because of limited resources and test schedule time.

\section{CONCLUDING REMARKS}

A convertible engine using variable inlet guide vanes (VIGV) to unload the fan aerodynamically was successfully tested on an outdoor test stand at NASA Lewis. The tests demonstrated that this type of engine could be used for propulsion of new high-speed V/STOL and rotorcraft needing both thrust and shaft power. For V/STOL the engine might also be used to cross-couple the fans of a two-engine aircraft, but the controls and dynamics for that application were not tested.

In the steady-state tests the engine was operated in the turboshaft, turbofan, and dual (combined fan and shaft) power modes. The engine ran smoothly except for a small region at high VIGV closure and high fan speed where fan-tip 
aeromechanical instability was found; otherwise, it was stable as speed, shaft power, and any of the variable hardware settings were changed. This instability is not considered to be a big problem for a new engine and could be avoided by changes in blade design.

For rotorcraft propulsion the engine would be used in the turboshaft or the dual power mode to drive a rotor for takeoff and low-speed flight. If thrust during takeoff is low, the VIGV would be closed and the engine fuel consumption would be about 25 percent more than that of a turbofan engine running at the same core power level. The additional fuel is needed because power is wasted in churning and heating the tip airflow with the VIGV closed. The wasted power is not detrimental to rotorcraft having engines sized for highspeed cruise, such as the X-wing, because the installed power would be great enough to permit one-engine inoperative (OEI) hover at sea level.

In high-speed cruise flight the engine would be operated in the turbofan mode with the VIGV open (or nearly open) to produce thrust or in dual power mode if shaft power is also needed for auxiliary equipment such as a compressor for X-wing blowing. The engine fuel consumption would be comparable to that of a conventional turbofan engine because the only change in fuel use comes from the inlet pressure loss across the VIGV. The loss is small when the VIGV are nearly open.

In dynamic performance tests with a specially built digital engine control system and using a waterbrake dynamometer for shaft load, the engine easily handled large torque and thrust command steps, as well as simulated flight maneuvers. The fastest thrust step was made by changing the VIGV closure at constant fan speed; in this control mode the response seems to be limited only by the VIGV slewing rate and would be useful for thrust vector control. During a large torque step the speed droop was 5.8 percent, which is comparable to the droop showk by production turboshaft engines. Simulated takeoff, $X$-wing conversion, and collective pitch change maneuvers were performed successfully with control anticipation, and response to a simulated gust load was performed successfully wi thout anticipation.

Engine performance was predictable with conventional analytical techniques and computer cycle programs, except for the fan-tip churning power loss with the VIGV closed. The power loss was more than expected, probably because of unusual fan-stage flow behavior at high VIGV closure. Other reported test results measured less churning loss with a VIGV/fan rotor/VEGV different from the CEST design; however, rotor-exit temperature was very high. Better understanding of fan flow behavior with closed VIGV might lead to reduction of churning loss without other problems.

The test results were applied to a study case in which one core engine failed in a two-engine cross-shafted V/STOL aircraft, and indicated that the "good" engine could supply enough power through the cross shaft to the fan on the inoperative side to keep thrust balanced. This action required changing VIGV defection in both engines, and total thrust was reduced. 


\section{REFERENCES}

1. W.P. Nelms and S.B. Anderson, "V/STOL Concepts in the United States Past, Present, and Future," Special Course on V/STOL Aerodynamics, AGARD-R-710, AGARD, Neviliy-Sur-Seine, France, 1984, pp. 4-1 to 4-44. (NASA TM-85938).

2. K.L. Abdalla and A. Brooks, "TF34 Convertible Engine System Technology Program," 38th Annual Forum of the American Helicopter Society, American Helicopter Society, Washington, D.C., 1982, pp. 163-169.

3. "Quiet Clean Short-Haul Experimental Engine (QCSEE) Under-the-Wing (UTW) Engine Composite Nacelle Test Report," Vol. 1, (R78AEG573-Vol. 1, General Electrical Company; NASA Contract NAS3-18021.) NASA CR-159471, 1979.

4. J.W. Schaefer, D.A. Sagerser, and E.G. Stakolich, "Dynamics of High-BypassEngine Thrust Reversal Using a Variable-Pitch Fan," NASA TM X-3524, 1977.

5. D.L. Wright and B.A. Jones, "Convertible Fan/Shaft Engine Variable Fan Geometry Investigation," USAAVLABS-TR-70-28, PWA-FR-3567, Pratt and Whitney Aircraft, 1970. (Avail. NTIS, AD-873018).

6. G.A. Bobula, R.H. Soeder, and L.A. Burkardt, "Effect of a Part-Span Variable Inlet Guide Vane on the Performance of a High-Bypass Turbofan Engine," AIAA Paper 81-1261, July 1981. (NASA TM-82617).

7. R.M. Williams and T.H. Boyd, "Preliminary X-Wing Characteristics and Propulsion Interface Document," DTNSRDC/TM-16-81/06, David W. Taylor Naval Ship Research and Development Center, May 1981.

8. J.C. Biggers and A.W. Linden, "X-Wing - A Low-DisC-Loading V/STOL for the Navy," SAE Paper 851772, Oct. 1985.

9. J.C. Gill, R.V. Earle, and H.M. Mar, "Rotorcraft Convertible Engine Study," (DDA-EDR-10978, Detroit Diesel A1lison; NASA Contract NAS3-22742), NASA CR-168161, 1982.

10. 3.D. Eisenberg and J.W. Bowles, "Folding Tilt Rotor Demonstrator Feasibility Study," 42nd Annual Forum of the American Helicopter Society, Vol. 2, American Helicopter Society, Washington, D.C., 1986, pp. 563-585.

11. J.G. McArdle, R.L. Barth, and L.A. Burkardt, "Steady-State Performance of a Turbofan/Turboshaft Convertible Engine with Variable Inlet Guide Vanes," NASA TP-2673, 1987.

12. H. Lindsay, "TF34 Convertible Engine System Technology Program," NASA CR-179453, 1986.

13. D.R. Gilmore, Jr., "TF34 Convertible Engine Control System Design," 40th Annual Forum of the American Helicopter Society, American Helicopter Society, Washington, D.C., 1984, pp. 609-620.

14. W.C. Nieberding and J.L. Pollack, "Optical Detection of Blade Flutter," ASME Paper 77-GT-66, Mar. 1977. (NASA TM X-73573). 
TABLE I. - CEST TF34 ENGINE RESPONSE TO SIMULATED ROTORCRAFT

MANEUVERS SHOWN IN FIGURE 14

\begin{tabular}{|l|c|c|c|c|c|}
\hline \multirow{2}{*}{ Maneuver } & $\begin{array}{c}\text { Command } \\
\text { time, } \\
\text { sec }\end{array}$ & \begin{tabular}{c} 
Shaft power \\
\cline { 5 - 6 }
\end{tabular} & $\begin{array}{c}\text { Thrust } \\
\text { reach from start to } \\
\text { of level, } \\
\text { sec }\end{array}$ & $\begin{array}{c}\text { Speed } \\
\text { overshoot, } \\
\text { percent }\end{array}$ & $\begin{array}{c}\text { Speed } \\
\text { droop, } \\
\text { percent }\end{array}$ \\
\hline $\begin{array}{l}\text { Takeoff } \\
\text { Takeoff with } \\
\text { maximum vector } \\
\text { control }\end{array}$ & 1.8 & 2.1 & 2.6 & 1.4 & 5.2 \\
$\begin{array}{c}\text { Collective pitch } \\
\text { Unanticipated }\end{array}$ & 1.0 & 1.0 & 1.0 & 3.5 & 2.7 \\
gust & .15 & .5 & .5 & 1.3 & 0 \\
x-wing conversion & 18.0 & (a) & (a) & 0 & 0 \\
\hline
\end{tabular}

afollowed commands.

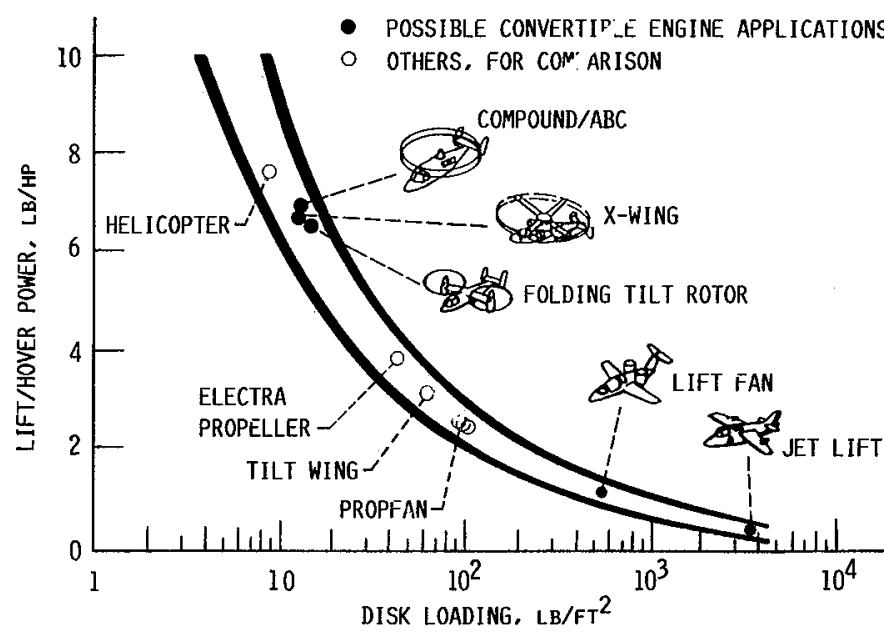

FIGURE 1. - AIRCRAFT THAT COULD USE CONVERTIBLE ENGINES. (DATA FROM REFS. 9 AND 11.) 


\section{ORIGINAL PAGE IS \\ OF POOR QUALITY}

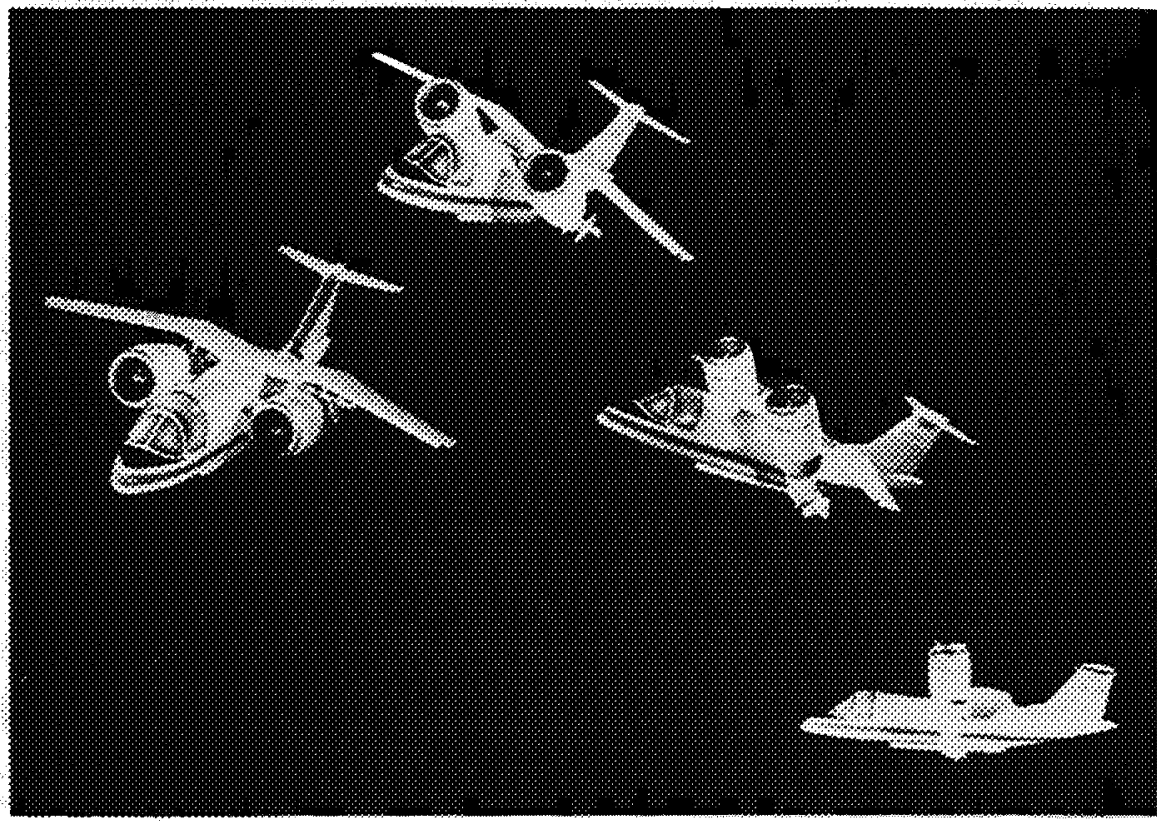

FIGURE 2. - GRUMMAN DESIGN 698 TILT NACELLE V/STOL AIRCRAFT.

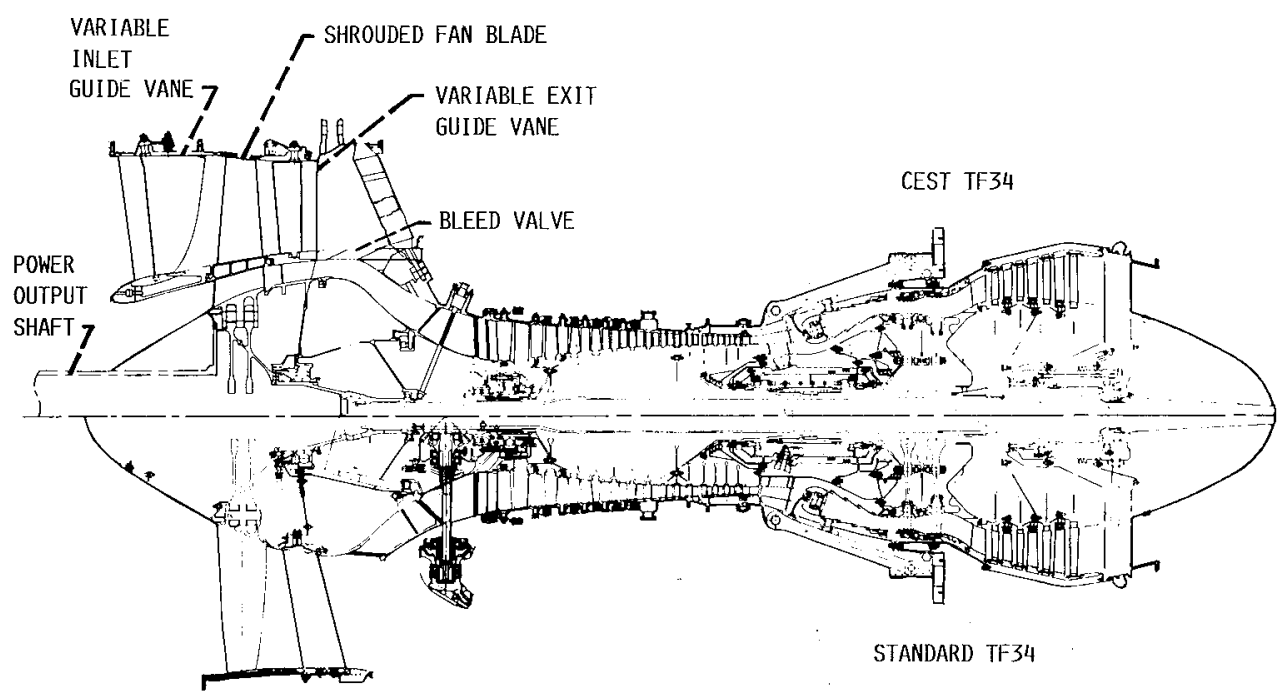

Figure 3. - TF34 CONVERTIBLE ENGINE COMPARED" With STANDARD TF34 ENGINE. 
3/8-IN.

CELL BY

2-IN.

THICK

HONEYCOMB

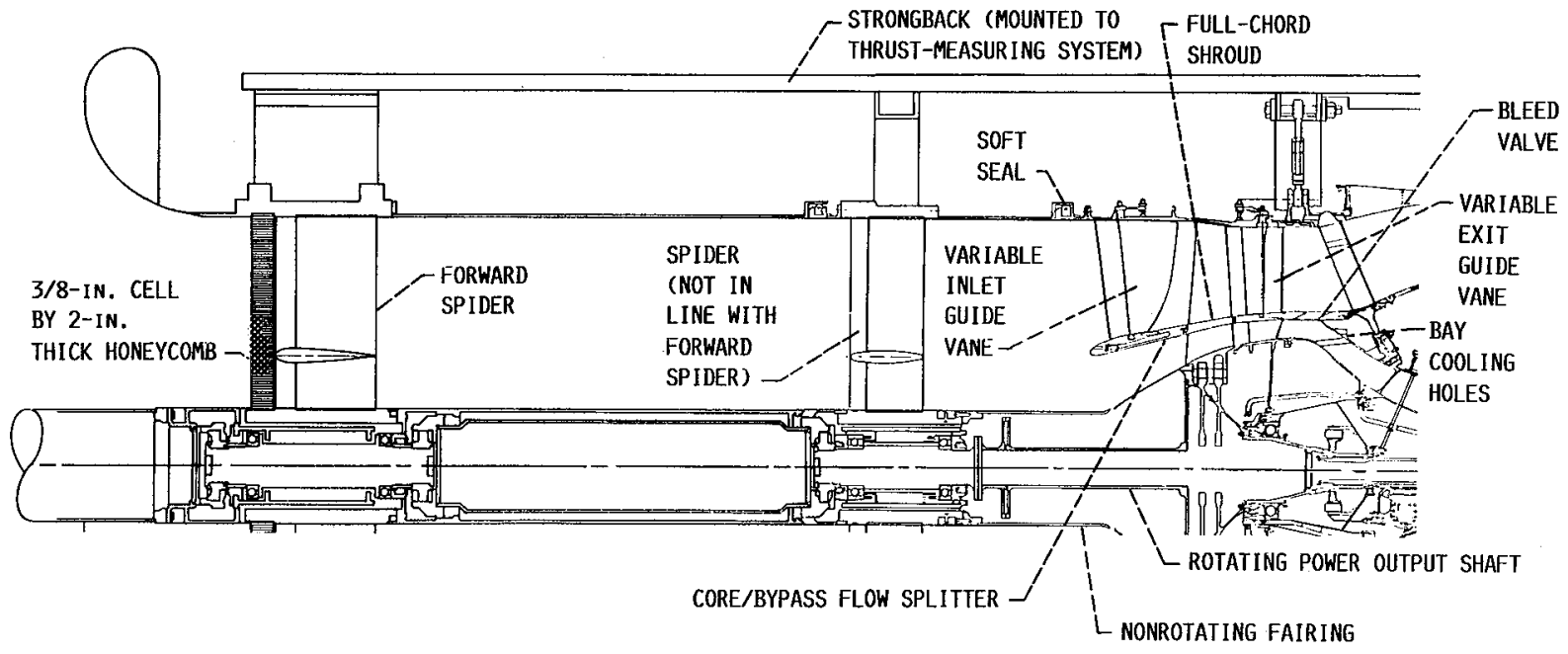

FIGURE 4. - CEST TF34 DESIGN FEATURES.
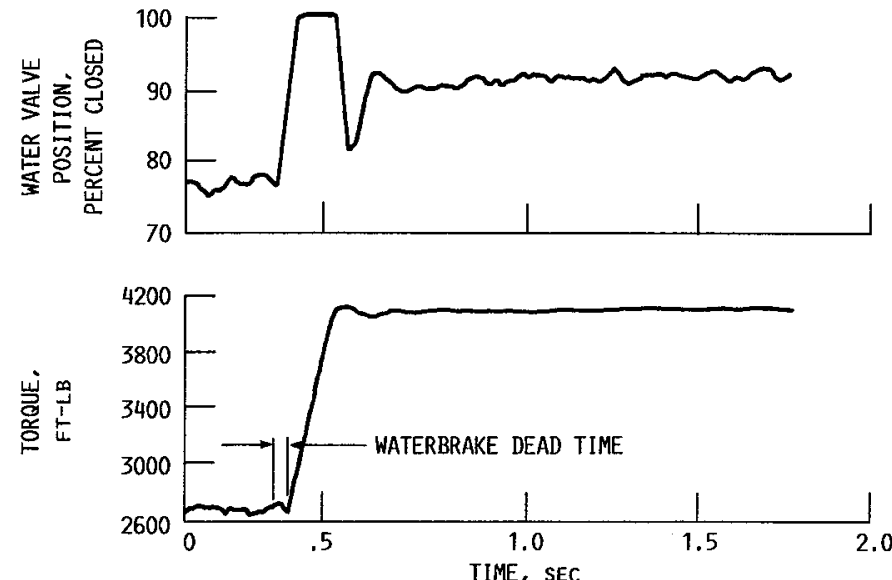

FIGURE 5. - CLOSED-LOOP RESPONSE OF WATERBRAKE TORQUE CONTROL SYSTEM TO STEP CHANGE. INITIAL FAN SPEED, NF, 85 PERCENT; CONSTANT ENGINE FUEL FLOW. 


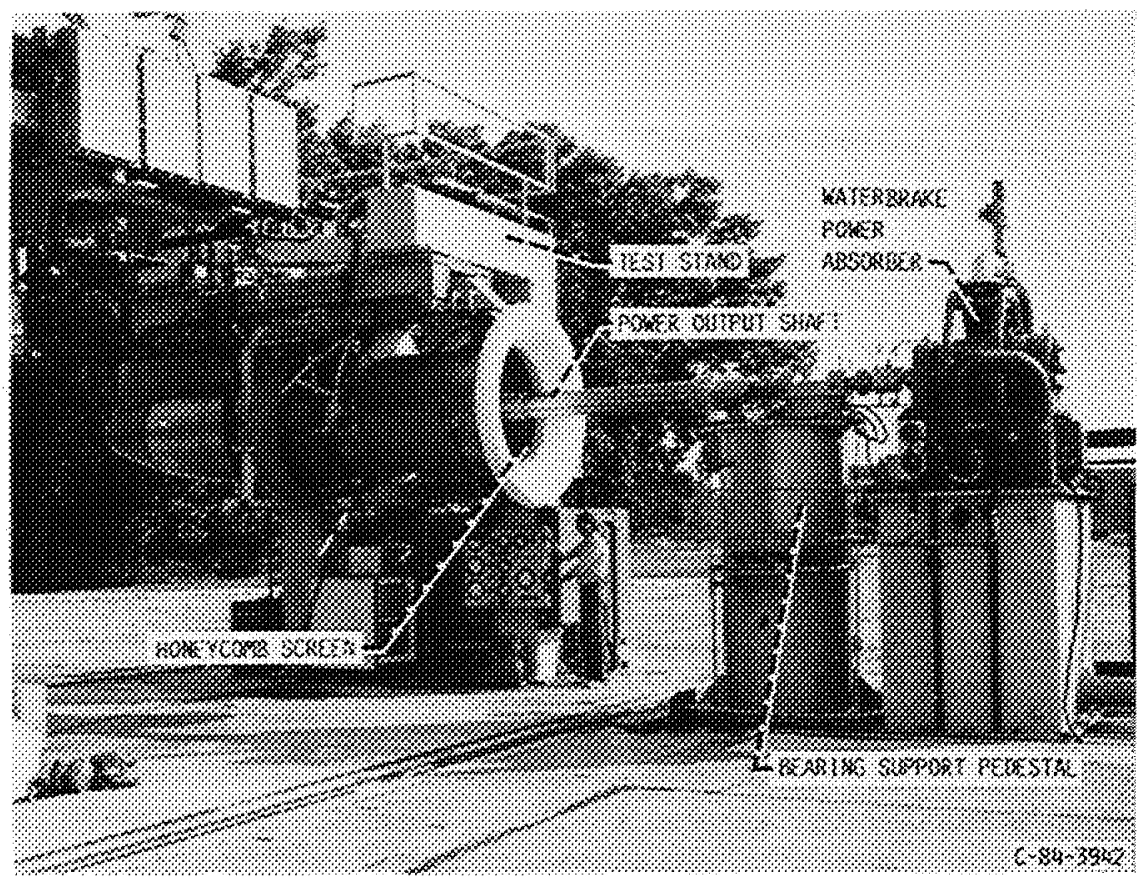

FIGURE 6. - CEST TF34 CONVERTIBLE ENGINE ON TEST STAND.

\section{ORIGINAL PAGE D OF POOR QUALITY}

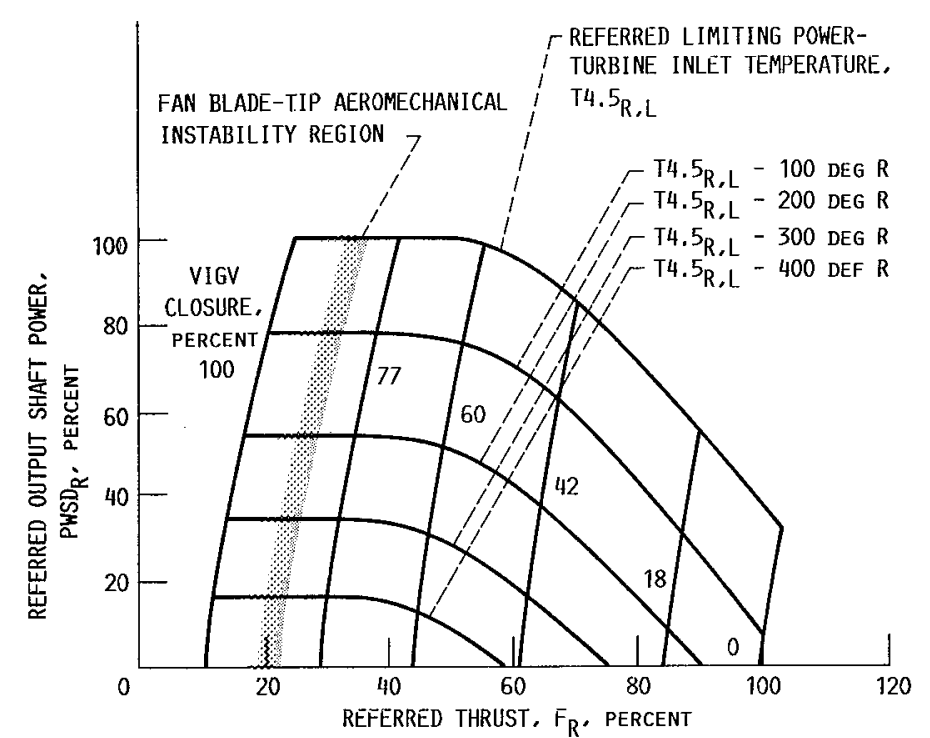

FIGURE 7. - SEA-LEVEL-STATIC PERFORMANCE OF CEST TF34 ENGINE. REFERRED FAN SPEED, $\mathrm{NF}_{R}, 90$ PERCENT.

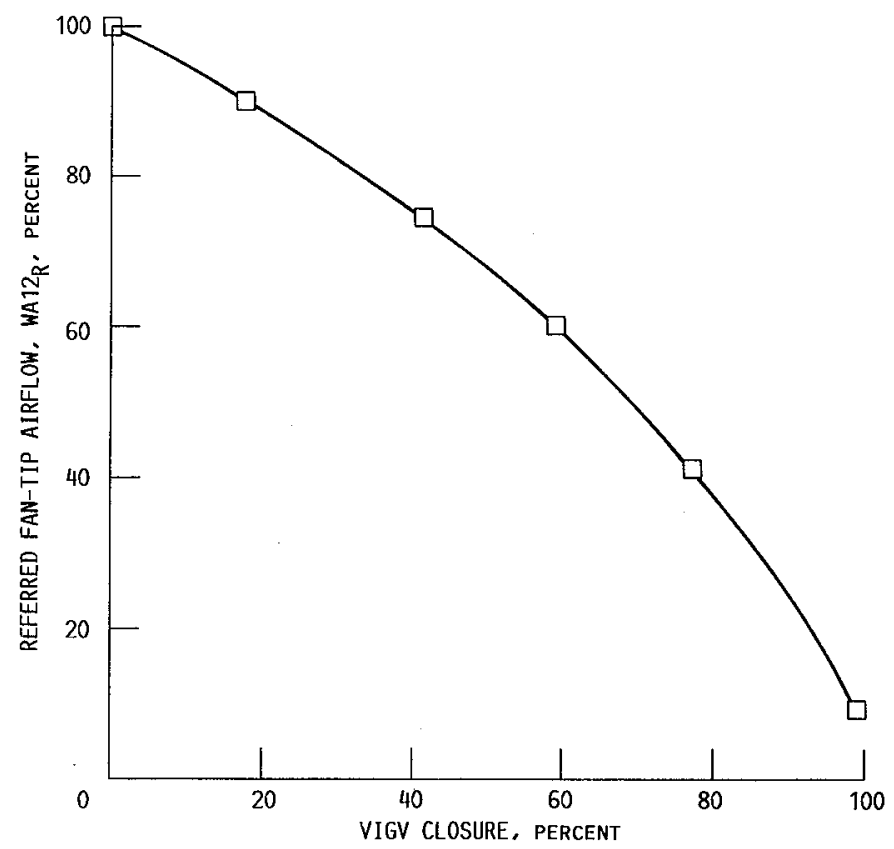

FIGURE 8. - FAN-TIP AIRFLOW IN TURBOSHAFT MODE. REFERRED FAN SPEED, NF$F_{R}, 90$ PERCENT. 


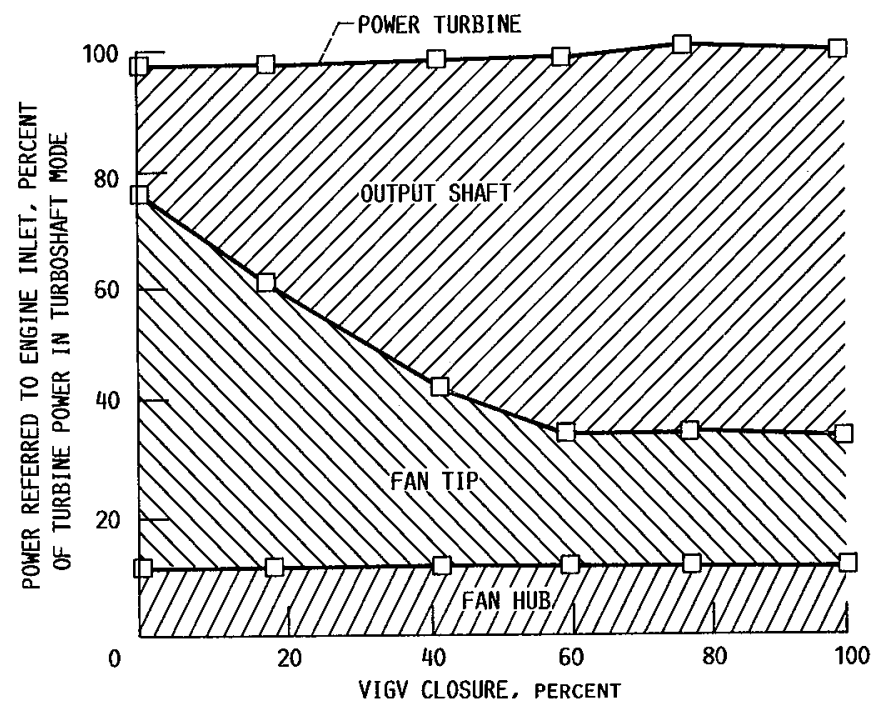

FIGURE 9. - POWER BALANCE IN TURBOSHAFT MODE. REFERRED FAN SPEED, $N_{R}, 90$ PERCENT.

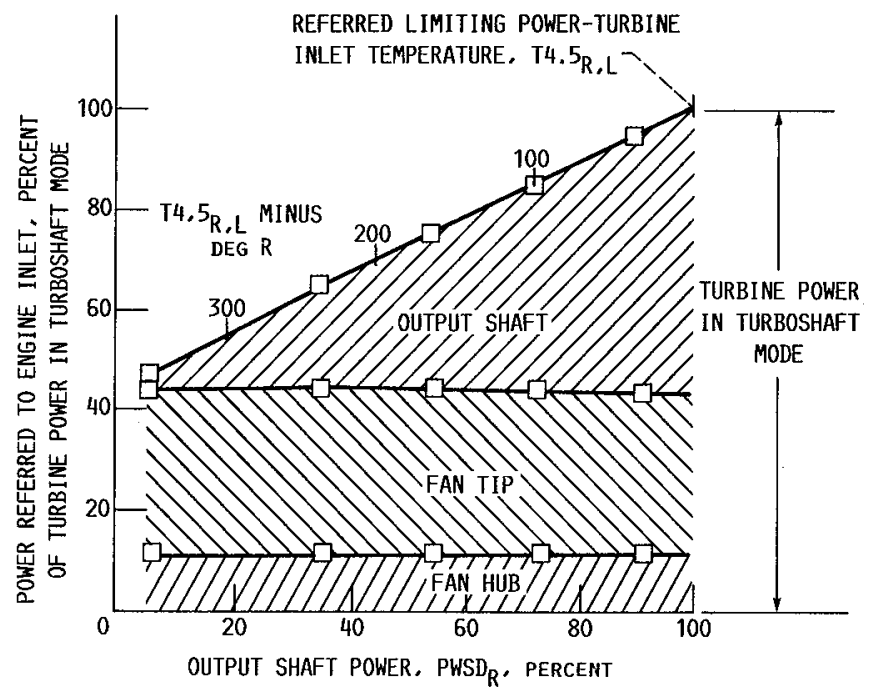

FIGURE 11. - TYPICAL POWER BALANCE IN DUAL POWER MODE. REFERRED FAN SPEED, NF $F^{\prime} 90$ PERCENT: VIGV CLOSURE, 42 PERCENT.

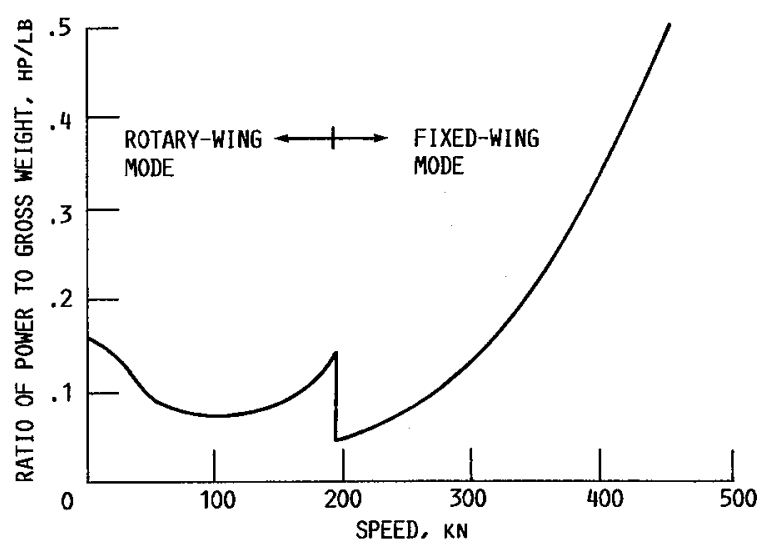

F GURE 10. - POWER REQUIRED FOR CONCEPTUAL X-WING AIRCRAFT. (FROM REF. 9.) SEA-LEVEL STANDARD CONDITIONS.

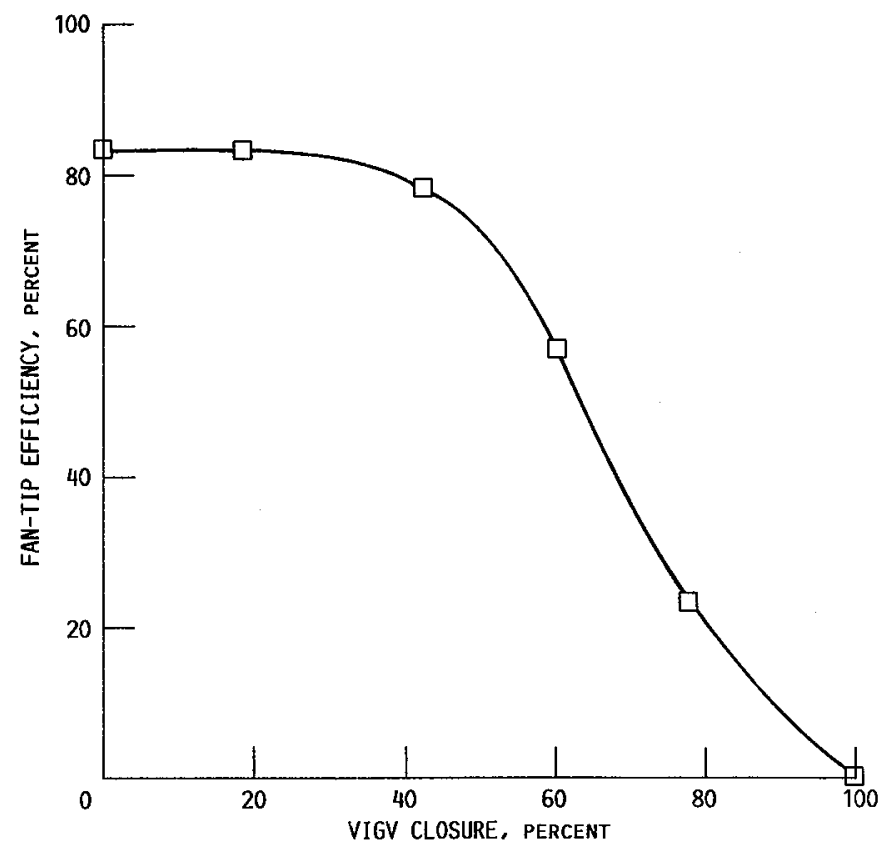

FIGURE 12 - FAN-TIP ADIABATIC COMPRESSION EFFICIENCY BASED ON FAN-INLET AND FAN-EXHAUST NOZZLE MEASUREMENTS. REFERRED FAN SPEED, NF, 90 PERCENT. 


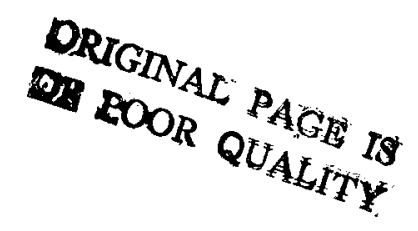

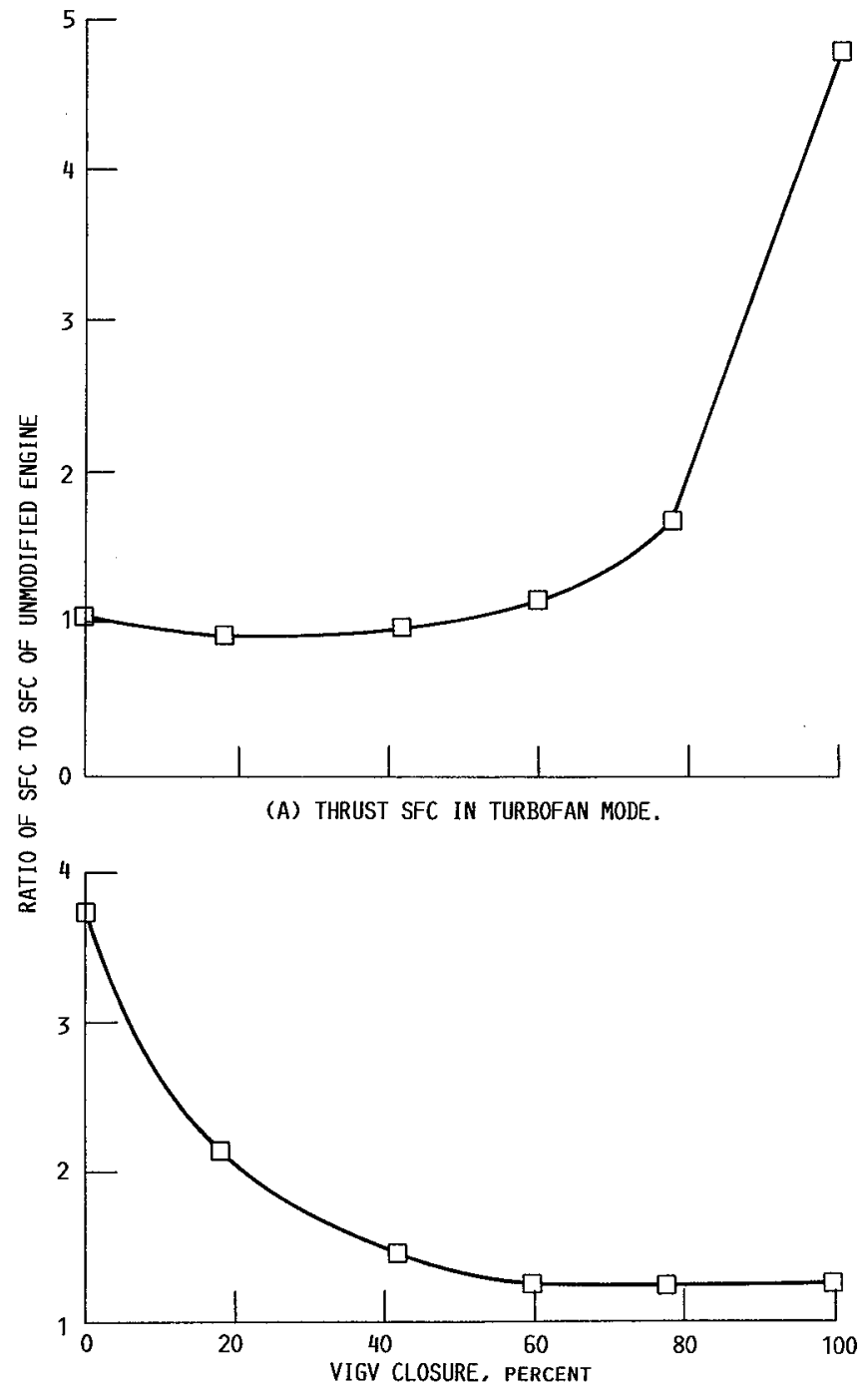

(B) SHAFT POWER SFC IN TURBOSHAFT MODE, POWER FOR UNMODIFIED ENGINE IS POWER DRIVING BYPASS FLOW THROUGH FAN TIP.

FIGURE 13. - SEA-LEVEL STATIC SPECIFIC FUEL CONSUMPTION (SFC). REFERRED FAN SPEED, $N F_{R}, 90$ PERCENT.

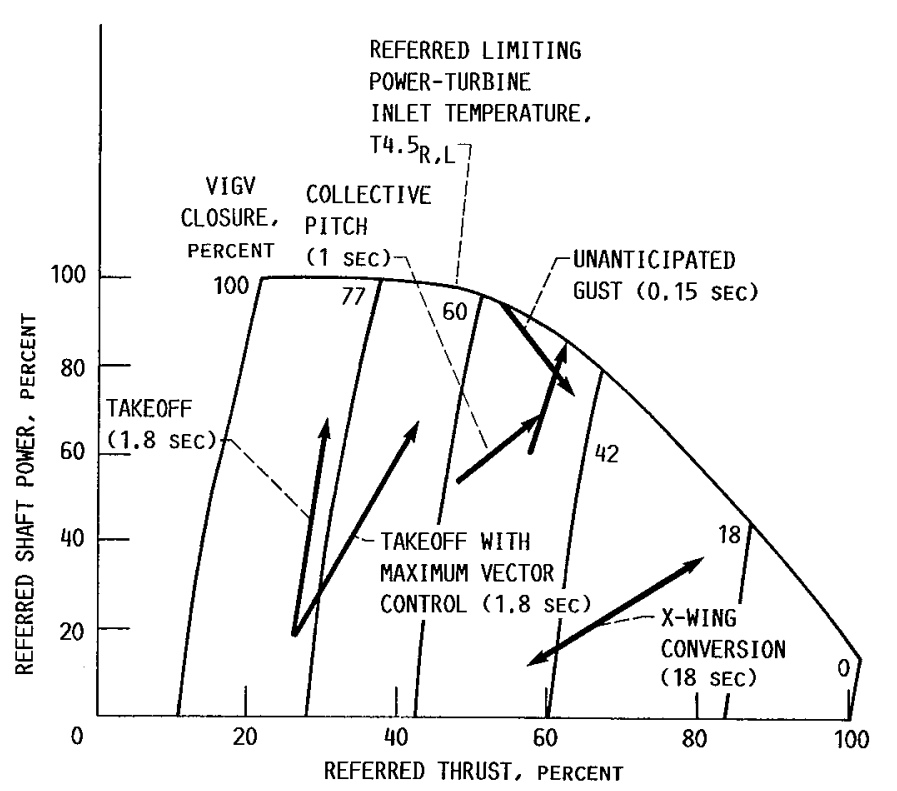

FIGURE 14. - SIMULATED ROTORCRAFT MANEUVERS TESTED WITH CEST TF34 ENGINE AND CONTROL SYSTEM. REFERRED FAN SPEED. NF ${ }_{R}$, 95 PERCENT; TIMES SHOWN ARE COMMANDED TIMES. 


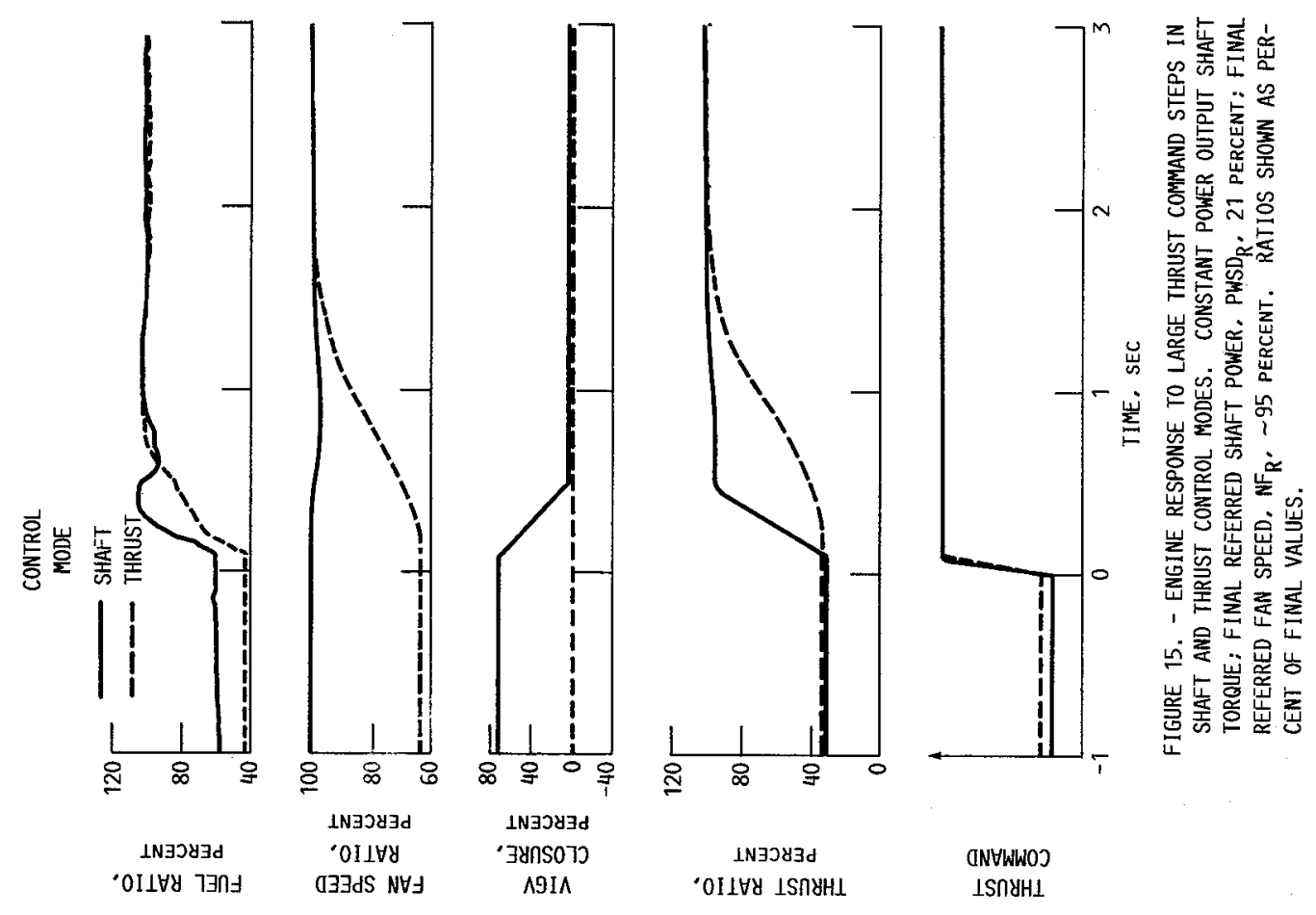



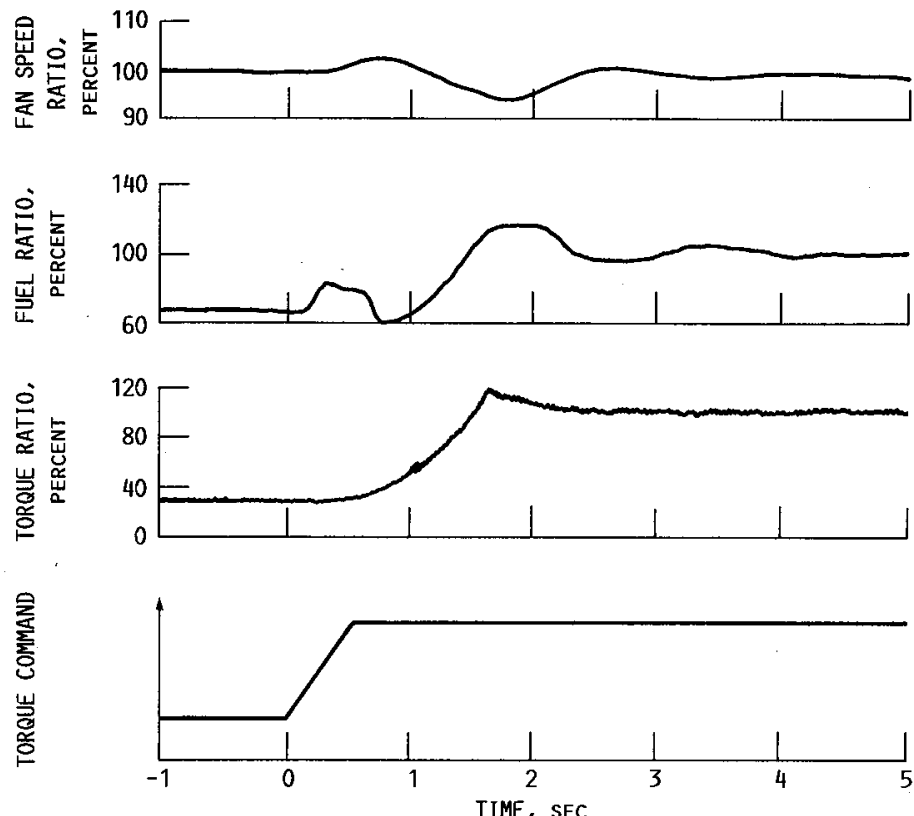

.FIGURE 16. - ENGINE RESPONSE TO LARGE POWER OUTPUT SHAFT TORQUE CHANGE. ENGINE CONTROL IN SHAFT MODE: VIGV CLOSURE, 77 PERCENT: REFERRED FAN SPEED. NF ${ }_{\mathrm{h}}$. AT END OF TRANSIENT, 95 PERCENT. RATIOS SHOWN AS PERCENT OF FINAL VALUE.

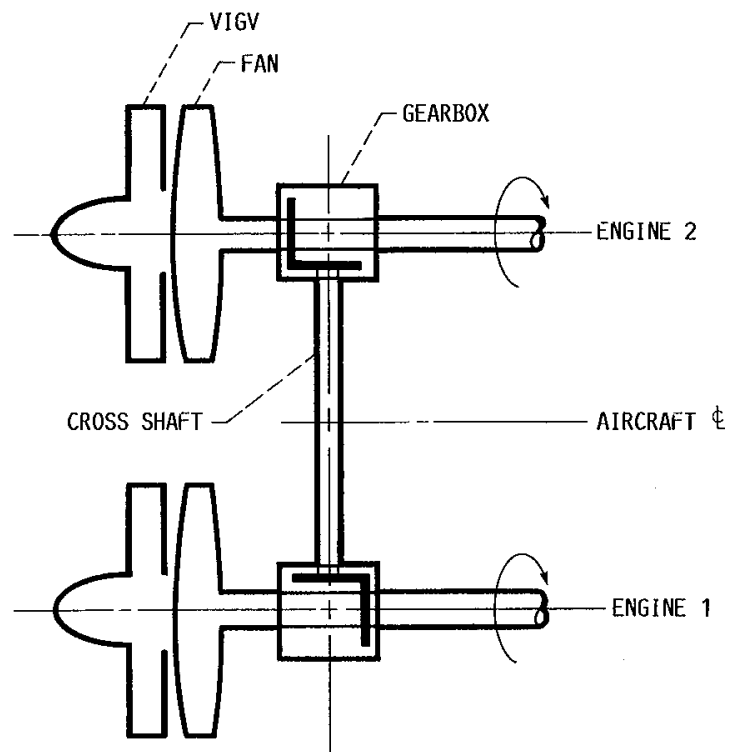

FIGURE 17. - TWO ENGINES WITH CROSS SHAFT. FAN SHAFTS MAY INCLUDE OVER-RUNNING CLUTCHES. 


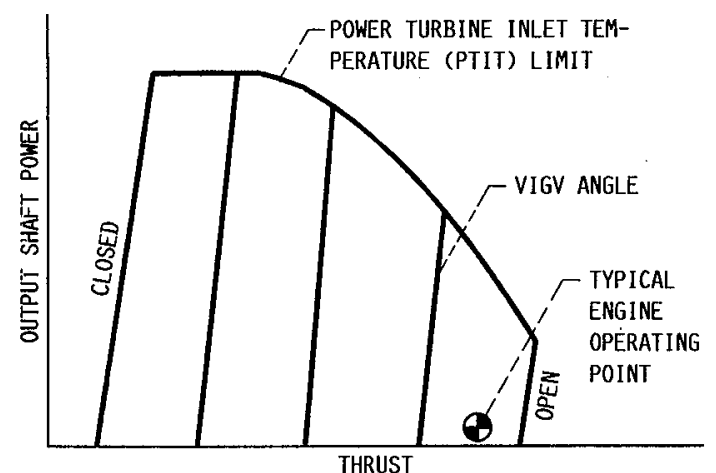

(A) BOTH ENGINES, OPERATING NORMALLY BEFORE FAILURE.

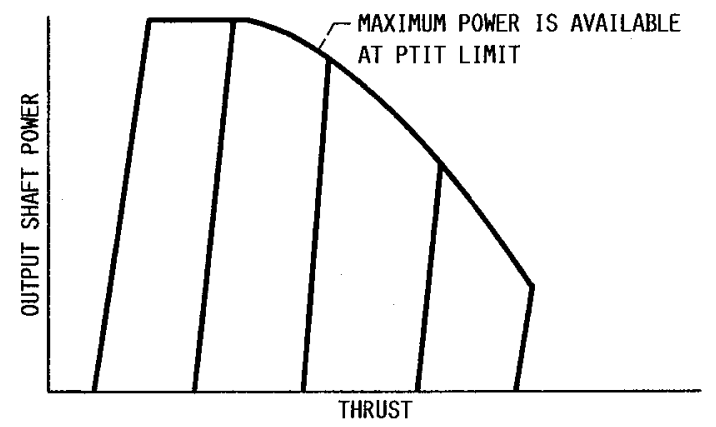

(C) "GOOD" ENGINE POWER AVAILABLE TO INOPERATIVE SIDE.

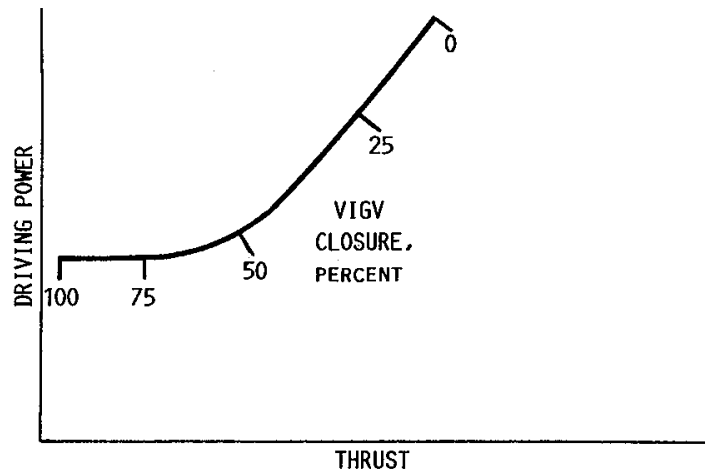

(B) POWER REQUIRED (LOAD) TO DRIVE FAN IN ENGIÑE WITH INOPERATIVE CORE,

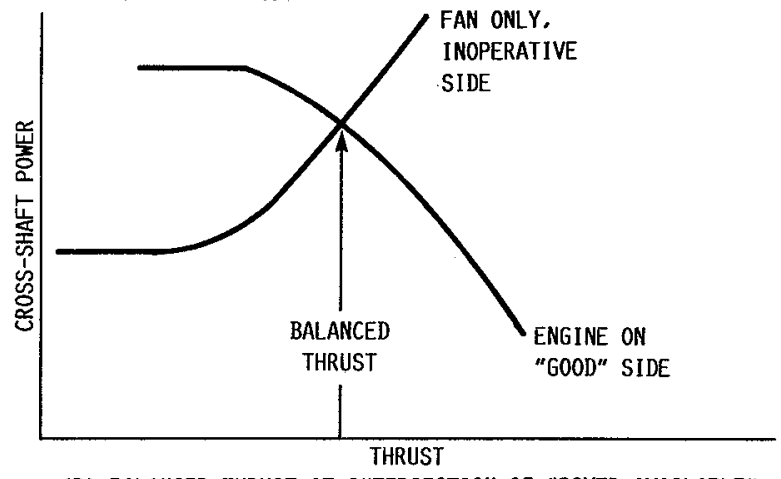

(D) BALANCED THRUST AT INTERSECTION OF "POWER AVAILABLE" AND "LOAD" LINES.

FIGURE 18. - CROSS-SHAFTED VIGV CONVERTIBLE ENGINES WITH ONE FAILED ENGINE.

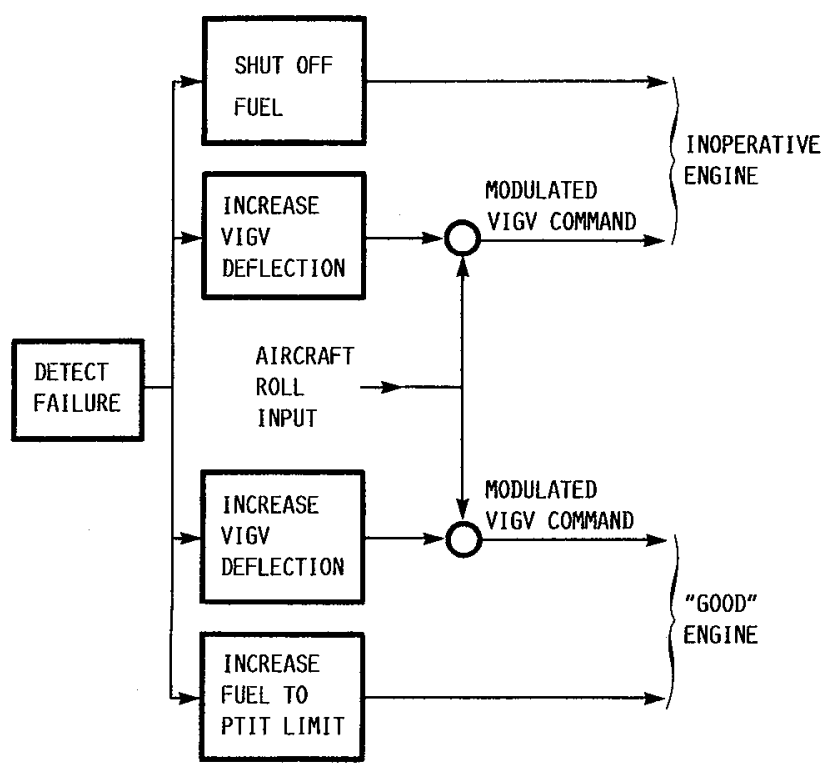

FIGURE 19. - RUDIMENTARY CONTROL CONCEPT FOR CROSS-SHAFTED CONVERTIBLE ENGINES, TO BALANCE THRUST WITH ONE ENGINE INOPERATIVE. 



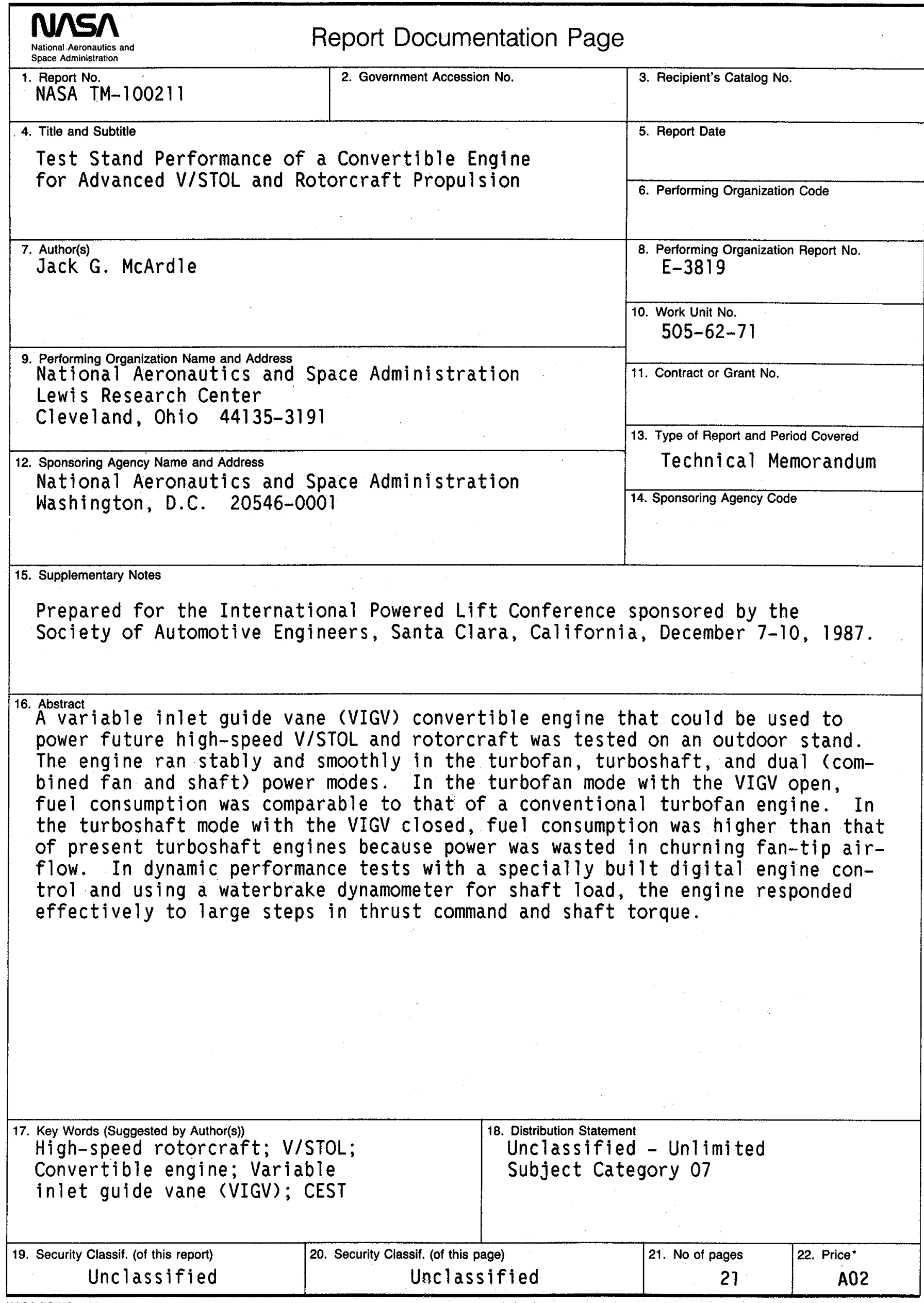

